\title{
NEUROCHEMICAL AND BEHAVIORAL EFFECTS OF ACUTE AND CHRONIC TREATMENT WITH APOMORPHINE IN RATS
}

\author{
J. K. Rowlett,' B. A. Mattingly ${ }^{1, *}$ and M. T. Bardo ${ }^{2}$ \\ 'Department of Psychology, Morehead State University, Morehead, KY 40351, U.S.A. and ${ }^{2}$ Department \\ of Psychology, University of Kentucky, Lexington, KY 40506, U.S.A.
}

\author{
(Accepted 27 July 1990)
}

\begin{abstract}
Summary - In three experiments, rats were injected once daily with $5.0 \mathrm{mg} / \mathrm{kg}$ apomorphine or vehicle and tested for locomotor activity for 10-14 days. In each experiment, apomorphine produced behavioral sensitization, characterized by a progressively greater increase in locomotor activity with each succeeding injection. On day 11 of testing, in an experiment designed to assess the synthesis of dopamine (DA), rats were injected with $5.0 \mathrm{mg} / \mathrm{kg}$ apomorphine or vehicle, followed by $100 \mathrm{mg} / \mathrm{kg} \mathrm{NSD}-1015$, an inhibitor of the enzyme $l$-aromatic amino acid decarboxylase. After administration of NSD-1015, concentrations of dihydroxyphenylalanine (DOPA) were determined in striatal and mesolimbic tissues by high performance liquid chromatography (HPLC) with electrochemical detection. The results revealed a significant decrease in accumulation of DOPA in both striatal and mesolimbic tissue after acute treatment with apomorphine. More important, chronic treatment with apomorphine produced a significant increase in accumulation of DOPA in both areas. In subsequent experiments, rats on day 14 of testing were sacrificed for determination of levels of DA, 3,4-dihydroxyphenylacetic acid (DOPAC) or specific binding of $\left[{ }^{3} \mathrm{H}\right]$ spiperone in the striatum and mesolimbic region. Although levels of DOPAC were significantly reduced in the regions of the brain after an acute injection of apomorphine, chronic treatment with apomorphine did not significantly affect levels of DA, DOPAC or specific binding of $\left[{ }^{3} \mathrm{H}\right]$ spiperone. These findings suggest that the development of behavioral sensitization to apomorphine may be related to an alteration in the synthesis of DA.
\end{abstract}

Key words-apomorphine, behavioral sensitization, dopamine, striatum, mesolimbic system.

Drugs that act by directly or indirectly stimulating central dopamine (DA) systems, often produce progressively greater behavioral responses with repeated administration. This behavioral sensitization effect has been demonstrated using several drugs that act as direct or indirect DA agonists, including cocaine, amphetamine and apomorphine (Castro, Abreu, Calzadilla and Rodriguez, 1985; Kalivas, Duffy, DuMars and Skinner, 1988; Mattingly, Gotsick and Salamanca, 1988; Reith, 1986; Robinson and Becker, 1986; Zahniser, Peris, Dwoskin, Curella, Yasuda, O'Keefe and Boyson, 1988). While the acute behavioral effects of DA agonists are similar, significant behavioral differences exist among these drugs in the development of behavioral sensitization. For example, chronic administration of amphetamine enhances amphetamine-induced stereotypy (i.e. repetitive sniffing, head and limb movements) and locomotor activity (Robinson and Becker, 1986). Similarly, chronic administration of cocaine enhances cocaine-induced stereotypy and locomotor activity (Kalivas et al., 1988; Reith, 1986). In contrast, chronic administration of apomorphine enhances locomotor activity but not stereotypy (Mattingly, Gotsick and Marin, 1988).

*To whom correspondence should be addressed.
Each of the sensitization-producing DA agonists has a different mechanism of action on central dopaminergic transmission. Cocaine, for example, enhances the activity of DA indirectly by inhibition of the uptake of dopamine (Zahniser et al., 1988). Amphetamine is also an indirect-acting DA agonist, producing its effects primarily by inducing release of DA (Zetterström, Sharp, Marsden and Ungerstedt, 1983). In contrast, apomorphine is a direct-acting DA receptor agonist (Creese, Hamblin, Leff and Sibley, 1983). The differential behavioral effects of DA agonists, with chronic administration, may be related to the differential mechanisms of action of each of these drugs on DA neurotransmission.

Much attention has been given in recent years to the neuropharmacological correlates of cocaine- and amphetamine-induced behavioral sensitization (see Robinson and Becker, 1986; Zahniser et al., 1988 for reviews). Consequently, the effects of amphetamine and cocaine on various indices of DA function are well characterized. In contrast, less is known of the neuropharmacological effects of chronic administration of apomorphine. Available evidence suggests that chronic treatment with apomorphine does not affect the binding of $\left[{ }^{3} \mathrm{H}\right]$ spiperone in the striatum of the mouse (Riffee, Wilcox, Vaughn and Smith, 1982) but the effect of chronic treatment with apomorphine 
on binding sites for DA in other pathways (e.g. mesolimbic) has not been determined. Similarly, the effect of chronic treatment with apomorphine on the synthesis and metabolism of DA in various DA terminal fields is unknown. The purpose of the present study, therefore, was to determine the effects of chronic treatment with apomorphine on various indices of DA function in striatal and mesolimbic terminal fields. In three experiments, rats were injected daily with a large dose of apomorphine to induce sensitization, using locomotor activity as a behavioral measure. In the first experiment, the synthesis of DA in anterior striatal and mesolimbic tissue was assessed after acute and chronic treatment with apomorphine by measuring the accumulation of dihydroxyphenylalanine (DOPA), after administration of an $l$-aromatic amino acid decarboxylase inhibitor. In a second experiment, changes in levels of DA and 3,4-dihydroxyphenylacetic acid (DOPAC). were measured after behavioral testing. Finally, a third experiment assessed the binding density of $\left[{ }^{3} \mathrm{H}\right]$ spiperone in striatal and mesolimbic regions after acute and chronic treatment with apomorphine.

\section{METHODS}

\section{Subjects}

Male Wistar albino rats, experimentally naive and weighing between $250-300 \mathrm{~g}$, were used in each experiment. All rats were housed individually, maintained on ad libitum food and water and a 12-hr light/dark cycle was held constant throughout the study. All behavioral testing was conducted during the light phase of the cycle.

\section{Activity testing apparatus}

Measures of activity were taken in two BRS/ Lehigh Valley cylindrical activity drums (Model 14503 ), which were $60 \mathrm{~cm}$ in diameter and $43 \mathrm{~cm}$ high. The interior of the drums was painted flat black and the floor was made of $4 \mathrm{~cm}$ diamond wire mesh. Each drum was located in a separate experimental cubicle that was kept totally dark throughout testing. Each drum was equipped with two banks of three infrared photocells mounted of the outside of the drums. The photocells were approximately $12 \mathrm{~cm}$ apart and $2.5 \mathrm{~cm}$ above the floor of the drum. The banks of photocells were connected to electromechanical counters, in an adjacent control room, by way of back-path eliminator diodes. Movement of the rat through a photocell beam sent a single pulse to the counters. Simultaneous pulses (i.e. pulses spaced less than $0.05 \mathrm{sec}$ apart), such as might occur when two beams were broken near their intersection, were recorded as a single count by this method. Thus, activity was defined as the cumulative number of interruptions of photobeams per unit time.

\section{Locomotor activity testing and dissections}

At the beginning of each experiment, the rats were randomly assigned to either the apomorphine- or vehicle-pretreatment condition. The rats received 13 daily subcutaneous injections of $5.0 \mathrm{mg} / \mathrm{kg}$ apomorphine hydrochloride (Sigma) or vehicle $(0.001 \mathrm{~N} \mathrm{HCl})$, except in the experiment assessing the synthesis of DA in which only 10 daily injections were administered. The dose injected was calculated, based on the weight of the salt of the drug and the volume of administration was held constant at $0.5 \mathrm{ml} / \mathrm{kg}$. The dose of apomorphine $(5.0 \mathrm{mg} / \mathrm{kg})$ and the length of administration (10-13 days) were chosen, based on a previous study, which demonstrated maximum locomotor sensitization using these parameters (Mattingly et al., 1988).

During the chronic pretreatment sessions, each rat was removed from its home cage, weighed and then injected with either apomorphine or vehicle. After the injection, the rats were returned to their home cage. Fifteen minutes later, the rats were placed in the activity drums and activity counts were recorded at 10 -min intervals for a total of $20 \mathrm{~min}$. All rats were tested with an approximately $24-\mathrm{hr}$ interval between each activity test session.

During the final session of each experiment, onehalf of the rats in each chronic pretreatment condition were randomly assigned to either the apomorphine- or vehicle-acute-challenge condition. During the drug challenge session of the DA synthesis experiment, the rats were injected with either $5.0 \mathrm{mg} / \mathrm{kg}$ apomorphine or vehicle. Fifteen minutes after the injection, the animals received the $l$-aromatic amino acid decarboxylase inibitor, NSD. 1015 ( $M$-hydroxybenzylhydrazine dihydrochloride, $100 \mathrm{mg} / \mathrm{kg}$, i.p., Sigma) and were sacrificed $30 \mathrm{~min}$ later by rapid decapitation. The brains were rapidly removed and placed on a ice-cold dissection plate. During the challenge session with drug, of the DA metabolite experiment, activity measures were taken in order to assess the effects of acute administration of apomorphine on locomotor activity and levels of metabolites. After activity testing $(20 \mathrm{~min}$ ), the animals were then sacrificed and the brains removed as in the DA synthesis experiment. During the drug challenge session of the binding experiment, each rat was injected with either $5.0 \mathrm{mg} / \mathrm{kg}$ apomorphine or vehicle and returned to its home cage. Fifteen minutes later, each animal was sacrificed by rapid decapitation. In all the experiments, samples of striatal (anterior to optic chiasm) and mesolimbic (nucleus accumbens septi and olfactory tubercles) tissue were dissected, frozen on dry-ice and then stored at $-70^{\circ} \mathrm{C}$ for the assay. Tissue samples used for the assays of synthesis and metabolites of DA were placed in 15 vols of $0.1 \mathrm{~N} \mathrm{HClO}_{4}$ before freezing.

\section{Determination of DOPA, DA and DOPAC}

Tissue samples were thawed and sonicated with a microhomogenizer (Vibracell, setting 80). The homogenate was centrifuged at $40,000 \mathrm{~g}$ for $10 \mathrm{~min}$ at $4^{\circ} \mathrm{C}$. Twenty microliters of supernatant were assayed for 
DOPA, DA and DOPAC using a high-pressure liquid chromatograph, with an electrochemical detector (Bioanalytical Systems, LC-304T) and a temperature-controlled $\left(25^{\circ} \mathrm{C}\right) 5 \mu \mathrm{m}$ column (Bioanalytical Systems, PN 6207). The mobile phase for determination of DOPA was prepared as described by Sparks and Slevin (1985). The mobile phase for determination of DA and DOPAC was prepared as described by Mayer and Shoup (1983). External standards for DOPA, DA and DOPAC (Sigma) were assayed daily.

\section{Receptor binding}

Sections of brain were thawed and homogenized, using a Brinkmann Polytron (5 sec, setting 6) in 100 vols of ice-cold $50 \mathrm{mM}$ Tris buffer $(\mathrm{pH} 7.4$ at $37^{\circ} \mathrm{C}$ ). The homogenate was then centrifuged at $40,000 \mathrm{~g}$ for $10 \mathrm{~min}$ at $4^{\circ} \mathrm{C}$. The supernatant was discarded and the pellet resuspended and briefly. sonicated (Vibracell, setting 80) in an equal volume of Tris buffer. This washing procedure was repeated twice and the tissue was resuspended in a final 200 vols of ice-cold $50 \mathrm{mM}$ Tris buffer, containing $120 \mathrm{mM} \mathrm{NaCl}, 5 \mathrm{mM} \mathrm{KCl}, 2 \mathrm{mM} \mathrm{CaCl}, 1 \mathrm{mM}$ $\mathrm{MgSO}_{4}, 10 \mu \mathrm{M}$ pargyline and $0.1 \%$ ascorbic acid $\left(\mathrm{pH} 7.4\right.$ at $\left.37^{\circ} \mathrm{C}\right)$. Tissue homogenates were pre-incubated at $37^{\circ} \mathrm{C}$ for $10 \mathrm{~min}$ and then placed on ice. After pre-incubation, $950 \mu \mathrm{l}$ of tissue sample were incubated at $37^{\circ} \mathrm{C}$ for $15 \mathrm{~min}$ with $0.4 \mathrm{nM}\left[{ }^{3} \mathrm{H}\right]$ spiperone (New England Nuclear, specific activity = $26.8 \mathrm{Ci} / \mathrm{mmol}$ ) and either $1.0 \mu \mathrm{M}$ haloperidol or an equal volume of the Tris buffer with ions. In previous experiments, it was found that $1.0 \mu \mathrm{M}$ haloperidol displaced $0.4 \mathrm{nM}\left[{ }^{3} \mathrm{H}\right]$ spiperone from fresh striatum of the rat, similar to $1.0 \mu \mathrm{M}(+)$ butaclamol (unpublished observations). Fifty $\mu \mathrm{M}$ ketanserin (Janssen Pharmaceuticals) was added to all tubes to displace $\left[{ }^{3} \mathrm{H}\right]$ spiperone from 5-hydroxytryptamine ${ }_{2}$ receptors (List and Seeman, 1981). Saturation studies were carried out in striatal tissues, using six concentrations of $\left[{ }^{3} \mathrm{H}\right]$ spiperone, ranging from 0.02 to $1.0 \mathrm{nM}$. The final incubation volume was $1.0 \mathrm{ml}$.

After incubation, the samples were returned to ice and filtered (Whatman GF/B glass fiber filters) under vacuum pressure. The filters were washed of unbound $\left[{ }^{3} \mathrm{H}\right]$ spiperone with two $5 \mathrm{ml}$ vols of ice-cold Tris buffer (no ions) and placed in glass vials with $8.0 \mathrm{ml}$ scintillation cocktail (Research Products Intl. 3a70B). The radioactivity was measured by liquid scintillation spectrometry, using a Packard 3380, with approximately $25 \%$ counting efficiency. Specific binding was defined as the difference in bound radioactivity, obtained in the presence and absence of haloperidol. All samples were assayed in duplicate.

\section{Analysis of data}

The pretreatment activity data were analyzed by mixed factor analysis of variance (ANOVA) with chronic pretreatment drug and acute challenge drug, as between groups factors and session as a repeated measure. The challenge treatment activity data were analyzed by $t$-tests, using the Scheffé procedure (family-wise error controlled at 0.05). Separate $2 \times 2$ factorial ANOVAs were used to analyze levels of DOPA, DA, DOPAC and the binding of $\left[{ }^{3} \mathrm{H}\right]$ spiperone for each region of the brain.

Saturation isotherms were obtained from duplicated pooled tissue (i.e. $n=2$ ), consequently, statistical comparisons between groups were not carried out. The $K_{D}$ and $B_{\max }$ values were derived by non-linear regression analysis, using the LIGAND software package (Munson and Rodbard, 1980). When a single concentration of radioligand was used, the $B_{\max }$ value was estimated using the equation:

$$
B_{\max }=B\left(L+K_{D}\right) / L
$$

In the equation, $B$ is the amount of $\left[{ }^{3} \mathrm{H}\right]$ spiperone specifically bound at radioligand concentration $L$ (Boyson, McGonigle and Molinoff, 1986). The $K_{D}$ values used in the equation were those obtained from the anterior striatum saturation experiments.

\section{RESULTS}

\section{Locomotor activity}

Figure 1 presents the mean activity counts of the four groups for the 13 chronic pretreatment activity test sessions for the receptor binding experiment. The results from the chronic pretreatment sessions of the other two experiments showed similar results to the chronic pretreatment sessions of the binding experiment (data not shown).

As may be seen in Figure 1, the four groups displayed comparable activity levels during the first session, but significant differences emerged with repeated testing. Chronic administration of apomorphine produced a progressively larger increase in activity with each succeeding injection $(P<0.05$, ANOVA). This increase was asymptotic by approximately the tenth session. In contrast, the vehicletreated groups revealed no significant change in activity with the sessions. Also, the challenge drug

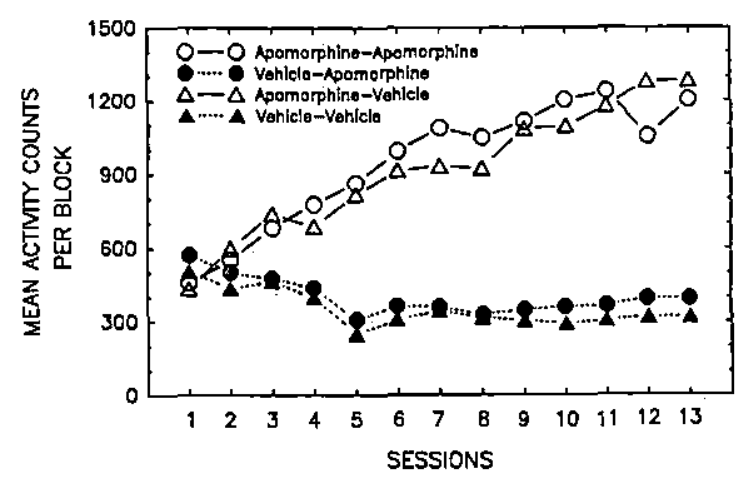

Fig. 1. Mean activity counts per $10 \mathrm{~min}$ block, for groups receiving $5.0 \mathrm{mg} / \mathrm{kg}$ apomorphine or vehicle, subdivided by challenge group for 13 sessions. Treatments are represented by chronically-administered pretreatment drug-acutely-administered challenge drug. Drug or vehicle was administered $15 \mathrm{~min}$ before each $20 \mathrm{~min}$ session. 


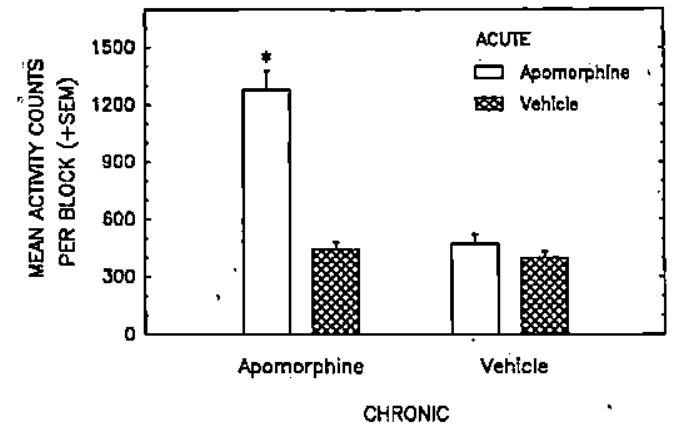

Fig: 2. Mean activity counts per $10 \mathrm{~min}$ block on day 14 (acute challenge session) of testing. The dose of apomorphine used was $5.0 \mathrm{mg} / \mathrm{kg}$. Drug or vehicle was administered $15 \mathrm{~min}$ before each $20 \mathrm{~min}$ session. ${ }^{*} P<0.05$ vs chronic apomorphine-acute vehicle challenge and the two chronic vehicle groups ( $t$-test, Scheffe's procedure).

groups displayed no significant differences during the pretreatment sessions, indicating that no inherent differences existed prior to the challenge test.

Figure 2 presents the activity data from day 14 of the experiment on metabolites of DA. As may be seen from the figure, animals pretreated with apomorphine and challenged with apomorphine displayed higher levels of activity than the other three groups $(P<0.05$, Scheffe's test). The latter three groups were not significantly different from one another in levels of activity.

\section{Accumulation of DOPA}

Table 1 presents mean accumulation values for DOPA after chronic and acute treatment with apo- morphine. In both striatal and mesolimbic tissues, acute administration of apomorphine decreased the accumulation of DOPA $(P<0.05$, main effect of acute administration of drug, ANOVA). More important, chronic treatment with apomorphine resulted in a significant increase in the accumulation of DOPA in both the striatal and mesolimbic tissues compared to chronic treatment with vehicle $(P<0.05$, main effect of chronic administration of drug, ANOVA). There was no significant interaction between chronic and acute treatment with drug in either region.

\section{Dopamine and DOPAC}

Table 2 presents the mean concentrations of DA and DOPAC. Chronic treatment with apomorphine did not produce significant changes in levels of DA in either the striatal or mesolimbic tissues. Similarly, levels of DOPAC in both striatal and mesolimbic tissues were not affected by chronic treatment with apomorphine. In contrast, acute challenge injections of apomorphine resulted in a significant decrease in concentrations of DOPAC in both regions of the brain $(P<0.05)$. This apomorphine-induced decrease in levels of DOPAC, however, did not differ for rats pretreated chronically with apomorphine or vehicle.

\section{Receptor binding}

Table 3 presents the mean specific binding of $\left[{ }^{3} \mathrm{H}\right]$ spiperone and estimates of $B_{\max }$ in striatal and mesolimbic tissue. As may be seen in Table 3, chronic treatment with apomorphine and acute challenge

Table 1. Changes in accumulation of DOPA induced by acute and chronic administration of apomorphine after inhibition of DOPA decarboxylase by NSD-1015 in rats ( $n=8$ per group)

\begin{tabular}{lcc}
\hline & \multicolumn{2}{c}{ Mean $\mu \mathrm{g}$ DOPA/g wet tissue weight \pm SEM } \\
\cline { 2 - 3 } Treatment (chronic-acute) & Anterior striatum & Mesolimbic region \\
\hline Apomorphine-Apomorphine & $1.46 \pm 0.12^{\mathrm{a} . \mathrm{b}}$ & $1.85 \pm 0.19^{\mathrm{a}, \mathrm{b}}$ \\
Vehicle-Apomorphine & $1.18 \pm 0.11^{\mathrm{b}}$ & $1.75 \pm 0.22^{\mathrm{a}}$ \\
Apomorphine-Vehicle & $4.14 \pm 0.29^{\mathrm{b}}$ & $3.04 \pm 0.15^{\mathrm{b}}$ \\
Vehicle-Vehicle & $3.38 \pm 0.23$ & $2.41 \pm 0.12$ \\
\hline
\end{tabular}

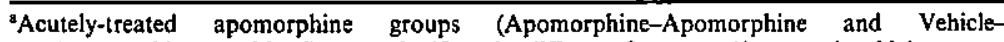
Apomorphine combined) were significantly different from acutely-treated vehicle groups (Apomorphine-Vehicle and Vehicle-Vehicle combined), analysis of variance, main effect of acute treatment with drug, $P<0.05$.

bChronically-treated apomorphine groups (Apomorphine-Apomorphine and ApomorphineVehicle combined) were significantly different from chronically-treated vehicle groups (Vehicle-Apomorphine and Vehicle-Vehicle combined), analysis of variance, main effect of chronic treatment with drug, $P<0.05$.

Table 2. Mean values for DA and DOPAC after acute and chronic treatment with apomorphine in rats $(n=9-10$ per group)

\begin{tabular}{lccccc}
\hline & \multicolumn{3}{c}{ Mean $\mu \mathrm{g} / \mathrm{g}$ wet tissue weight \pm SEM } \\
\cline { 2 - 3 } & \multicolumn{2}{c}{ Anterior striatum } & & \multicolumn{2}{c}{ Mesolimbic region } \\
\cline { 2 - 3 } \cline { 5 - 6 } Treatment (chronic-acule) & DA & DOPAC & & DA & DOPAC \\
\cline { 2 - 5 } Apomorphine-Apomorphine & $16.3 \pm 1.07$ & $2.2 \pm 0.15^{\mathrm{a}}$ & & $6.1 \pm 0.43$ & $0.9 \pm 0.07^{\mathrm{a}}$ \\
Vehicle-Apomorphine & $15.5 \pm 1.09$ & $2.4 \pm 0.10^{\mathrm{a}}$ & & $6.2 \pm 0.10$ & $1.1 \pm 0.07^{\mathrm{a}}$ \\
Apomorphine-Vehicle & $15.5 \pm 1.42$ & $3.5 \pm 0.35$ & & $6.2 \pm 0.21$ & $1.6 \pm 0.10$ \\
Vehicle-Vehicle & $15.4 \pm 1.22$ & $3.3 \pm 0.32$ & & $6.2 \pm 0.26$ & $1.6 \pm 0.08$ \\
\hline
\end{tabular}

"Acutely-treated apomorphine groups (Apomorphine-Apomorphine and Vehicle-Apormorphine combined) were significantly different from acutely-treated vehicle groups (ApomorphineVehicle and Vehicle-Vehicle combined), analysis of variance, main effect of acute treatment with drug, $P<0.05$. 
Table 3. Specific binding of $0.4 \mathrm{nM}\left[{ }^{3} \mathrm{H}\right]$ spiperone after acute and chronic treatment with apomorphine in rats ( $n=10$ per group)

\begin{tabular}{|c|c|c|c|c|}
\hline \multirow[b]{3}{*}{ Treatment (chronic-acute) } & \multicolumn{4}{|c|}{ Mean $\mathrm{fmol} / \mathrm{mg}$ wet tissue weight $\pm \mathrm{SEM}$} \\
\hline & \multicolumn{2}{|c|}{ Anterior striatum } & \multicolumn{2}{|c|}{ Mesolimbic region } \\
\hline & Bound & $B_{\max }$ & Bound & $B_{\max }$ \\
\hline $\begin{array}{l}\text { Apomorphine-Apomorphine } \\
\text { Vehicle-Apomorphine } \\
\text { Apomorphine-Vehicle } \\
\text { Vehicle-Vehicle }\end{array}$ & $\begin{array}{l}15.9 \pm 0.7 \\
15.5 \pm 0.4 \\
19.0 \pm 0.6 \\
17.9 \pm 0.6\end{array}$ & $\begin{array}{l}21.9 \pm 1.0 \\
21.7 \pm 0.6 \\
24.2 \pm 0.8 \\
23.3 \pm 0.8\end{array}$ & $\begin{array}{l}5.1 \pm 1.2 \\
5.4 \pm 1.2 \\
5.0 \pm 1.5 \\
5.7 \pm 1.8\end{array}$ & $\begin{array}{l}7.0 \pm 1.6 \\
7.6 \pm 1.7 \\
6.4 \pm 1.9 \\
7.4 \pm 2.3\end{array}$ \\
\hline
\end{tabular}

with apomorphine did not significantly affect the binding of $\left[{ }^{3} \mathrm{H}\right]$ spiperone in either the striatal or mesolimbic tissues $(P>0.05$ in each case).

Figure 3 presents saturation curves, Scatchard plots (inset), $K_{D}$ and $B_{\max }$ values for striatal tissue of rats treated chronically with apomorphine. Scatchard plots were linear and subsequent LIGAND analyses indicated that the curves were best fit fed to a one-site model. Thus, within the concentration range used, $\left[{ }^{3} \mathrm{H}\right]$ spiperone labelled a homogeneous population of

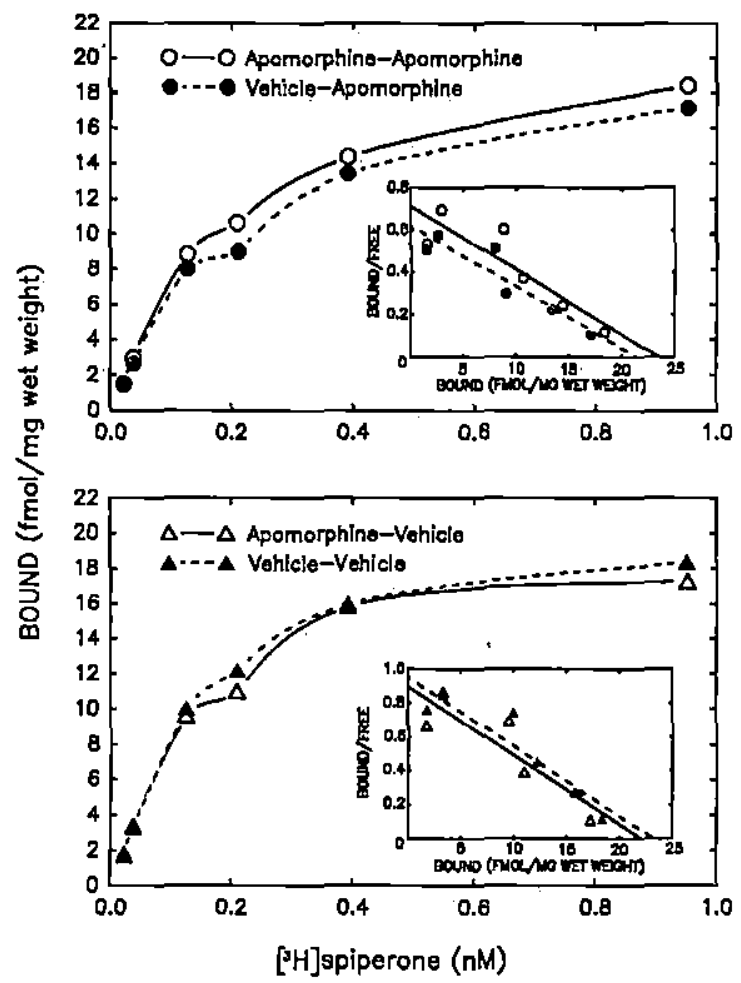

Fig. 3. Saturation curves and Scatchard plots (inset) for the binding of $\left.{ }^{3} \mathrm{H}\right]$ spiperone to anterior striatum of the rat. The top graph represents groups receiving a challenge of $5.0 \mathrm{mg} / \mathrm{kg}$ apomorphine on session 14 after chronic pretreatment with $5.0 \mathrm{mg} / \mathrm{kg}$ apomorphine or vehicle. The bottom graph represents groups receiving challenge with vehicle on session 14 after chronic pretreatment with $5.0 \mathrm{mg} / \mathrm{kg}$ apomorphine or vehicle. The $K_{D}$ and $B_{\max }$ values are as follows: Apomorphine-Apomorphine, $K_{D}=0.15 \mathrm{nM}$; $B_{\max }=22.39 \mathrm{fmol} / \mathrm{mg}$ wet tissue weight; Vehicle-Apomorphine, $K_{D}=0.16 \mathrm{nM}, B_{\max }=20.72 \mathrm{fmol} / \mathrm{mg}$ wet weight; Apomorphine-Vehicle, $K_{D}=0.11 \mathrm{nM}, B_{\max }=20.8 \mathrm{fmol} / \mathrm{mg}$ wet weight; Vehicle-Vehicle, $K_{D}=0.12 \mathrm{nM}, B_{\max }=$ $21.96 \mathrm{fmol} / \mathrm{mg}$ wet weight. binding sites. No differences between chronically treated apomorphine and vehicle groups were apparent in the saturation isotherms, obtained after an acute challenge with either apomorphine (Fig. 3, top panel) or vehicle (Fig. 3, bottom panel).

\section{DISCUSSION}

Consistent with previous studies (e.g. Castro et al., 1985; Mattingly et al., 1988), the present results clearly demonstrated the development of sensitization to apomorpine in rats, using locomotor activity as a behavioral measure. Moreover, as in a previous study (Mattingly et al., 1988), no evidence of conditioned hyperactivity was observed in the present study, when sensitized rats were injected with vehicle rather than apomorphine. This latter finding suggests that the development of behavioral sensitization to apomorphine cannot be explained by conditioning factors alone. It should be noted, however, that although conditioned hyperactivity has not been observed in rats sensitized to apomorphine, the potential involvement of conditioning factors cannot be dismissed since drug-associated contextual stimuli have been shown to facilitate the development of behavioral sensitization to apomorphine (Mattingly and Gotsick, 1989).

The present study found that the accumulation of DOPA was increased after chronic treatment with apomorphine in both the striatum and the mesolimbic region. One possible interpretation of the observed increase in synthesis of DA is that chronic administration of apomorphine may produce subsensitivity of autoreceptors. Autoreceptors for DA appear to be part of a negative feedback loop which regulates the firing rate of DA neurons, as well as the synthesis and release of DA (Roth, 1984). By inducing subsensitivity of autoreceptors, chronic administration of apomorphine may enhance the basal firing rate, release and synthesis of DA. In support of this subsensitivity hypothesis, the acute apomorphineinduced inhibition of the firing rate of DA neurons in the striatum and substantia nigra has. been shown to be significantly attenuated chronic treatment with apomorphine in large doses (Rebec and Lee, 1982).

In contrast, behavioral experiments utilizing administration of small doses of apomorphine have not 
demonstrated results consistent with the idea of an apomorphine-induced decrease in the sensitivity of autoreceptors. Administration of small doses of apomorphine appears to decrease locomotor activity, an effect proposed to be autoreceptor-specific (Skirboll, Grace and Bunney, 1979). Studies assessing the effects of chronic administration of small doses of apomorphine have demonstrated that both the ability of small doses of apomorphine to attenuate amphetamine-induced sensitization (Riffee, Wanek and Wilcox, 1987) and the ability of apomorphine to decrease locomotor activity (Mattingly et al., 1988) does not change with repeated injections. Likewise, in the present study, the decrease in levels of DOPAC, observed after acute treatment with apomorphine was not altered by chronic treatment with apomorphine. The acute decrease in levels of DOPAC is consistent with other reports (e.g. Bannon and Roth, 1983; Westrink and Korf, 1976) and is thought to reflect stimulation of DA autoreceptors. Together, these behavioral and neurochemical results suggest that the autoreceptors maintain their sensitivity. An alternative explanation would be that a subset of autoreceptors, modulating synthesis of DA, as opposed to autoreceptors modulating release of DA, may be preferentially affected by chronic administration of apomorphine (Wolf and Roth, 1987). However, it is also possible that chronic administration of apomorphine may produce a significant increase in synthesis of DA, independent of stimulation of autoreceptors, as recent reports have suggested that apomorphine may have a direct action upon tyrosine hydroxylase (cf. Riffee et al., 1987; Saller and Salama, 1986).

The density of binding sites for DA, as measured by specific binding of $\left[{ }^{3} \mathrm{H}\right]$ spiperone in striatal and mesolimbic tissue, was not significantly affected by chronic administration of apomorphine. Consistent with this result, Riffee et al. (1982) reported no significant changes in the binding of $\left[{ }^{3} \mathrm{H}\right]$ spiperone in striatum of the mouse after chronic treatment with large doses of apomorphine. Likewise, chronic treatment with amphetamine and cocaine do not appear to reliably aiter the density of binding sites for DA (see Robinson and Becker, 1986; Zahniser et al., 1988). Thus, apomorphine-induced sensitization, like amphetamine- and cocaine-induced sensitization, does not appear to be mediated by alterations in the number of postsynaptic binding sites for DA. It is, of course, possible that chronic treatment with apomorphine may result in significant changes in the $D_{1}$ receptors subtype, which may be related to the development of behavioral sensitization. Apomorphine is reported to be a partial agonist at $D_{1}$ sites, as well as a full agonist at $\mathrm{D}_{2}$ sites (Creese et al., 1983). Unfortunately, the potential involvement of $D_{1}$ sites cannot be determined from the present results because both spiperone and haloperidol bind with high affinity primarily to $D_{2}$ receptors.
Acknowledgements - We gratefully acknowledge the technical assistance of Rosalyn Ennis and Jamison Graff in collecting some of these data. The authors would also like to thank R. C. Pierce for helpful comments on an earlier version of this manuscript. This research was supported by a Kentucky EPSCoR grant and Morehead State University faculty grants to B.A.M.

\section{REFERENCES}

Bannon M. J. and Roth R. H. (1983) Pharmacology of mesocortical dopamine neurons. Pharmac. Rev. 35: 53-68.

Boyson S. J., McGonigle P. and Molinoff P. B. (1986) Quantitative autoradiographic localization of $D_{1}$ and $D_{2}$ subtypes of dopamine receptors in rat brain. J. Neurosci. 6: $3177-3188$.

Castro R., Abreu P., Calzadilla C. H. and Rodriguez M. (1985) Increased or decreased locomotor response in rats following repeated administration of apomorphine de pends on dosage interval. Psychopharmacology 85: 333-339.

Creese I., Hamblin M. W., Leff S. E. and Sibley D. R. (1983) CNS dopamine receptors. In: Handbook of Psychopharmacology: Biochemical Studies of CNS Receptors (Iversen L. L., Iversen S. D. and Snyder S. H., Eds), pp. 81-138. Plenum Press, New York.

Kalivas P. W., Duffy P., DuMars L. A. and Skinner C. (1988) Behavioral and neurochemical effects of acute and daily cocaine administration in rats. $J$. Pharmac. exp. Ther. 245: 485-492.

List S. J. and Seeman P. (1981) Resolution of dopamine and serotonin receptor components of $\left[{ }^{3} \mathrm{H}\right]$ spiperone binding to rat brain regions, Proc. natn. Acad. Sci. U.S.A. 78: 2620-2624.

Mattingly B. A. and Gotsick J. E. (1989) Conditioning and experiential factors affecting the development of sensitization to apomorphine. Behav. Neurosci. 103: 1311-1317.

Mattingly B. A., Gotsick J. E. and Marin C. (1988) Locomotor activity and stereotypy in rats following repeated apomorphine treatments at $1-, 3-$, or 7-day intervals. Pharmac. Biochem. Behav. 31: 871-875.

Mattingly B. A., Gotsick J. E. and Salamanca K. (1988) Latent sensitization to apomorphine following repeated low doses. Behav. Neurosci. 102: 552-558.

Mayer G. S. and Shoup R. E. (1983) Simultaneous multiple electrode liquid chromatographic-electrochemical assay for catecholamines, indoleamines and metabolites in brain tissue. J. Chromat. 255: 533-544.

Munson P. J. and Rodbard D. (1980) LIGAND: A versatile computerized approach for characterization of ligandbinding systems. Analyt. Biochem. 107, 220-239.

Rebec G. V. and Lee E. H. (1982) Differential subsensitivity of dopaminergic and neostriatal neurons to apomorphine with long-term treatment. Brain Res. 250: 188-192.

Reith M. E. A. (1986) Effect of repeated administration of various doses of cocaine and WIN 35,065-2 on locomotor behavior of mice. Eur. J. Pharmac. 130: 65-72.

Riffee W. H., Wanek E. and Wilcox R. E. (1987) Prevention of amphetamine-induced behavioral hypersensitivity by concomitant treatment with microgram doses of apomorphine. Eur. J. Pharmac. 135: 255-258.

Riffee W. H., Wanek E. and Wilcox R. E. (1988) Apomorphine fails to inhibit cocaine-induced behavioral hypersensitivity. Pharmac. Biochem. Behav. 29: 239-242.

Riffee W. H., Wilcox R. E., Vaughn D. M. and Smith R. V. (1982) Dopamine receptor sensitivity after chronic dopamine agonists: Striatal ${ }^{3} \mathrm{H}$-spiroperidol binding in mice after chronic administration of high doses of apomorphine, $N$ - $n$-Propylnorapomorphine, and dextroamphetamine. Psychopharmacology 77: 146-149. 
Robinson T. E. and Becker J. B. (1986) Enduring changes in brain and behavior produced by chronic amphetamine administration: $A$ review and evaluation of animal models of amphetamine psychosis. Brain Res. Rev. 11: $157-198$.

Roth R. H. (1984) CNS dopamine autoreceptors: Distribution, pharmacology, and function. Ann. N.Y. Acad. Sci. 430: $27-53$.

Saller C. F. and Salama A. I. (1986) Apomorphine enantiomers' effects on dopamine metabolism: Receptor and non-receptor related actions. Eur. J. Pharmac. 121: 181-188.

Skirboll L. R., Grace A. A. and Bunney B. S. (1979) Dopamine auto- and postsynaptic receptors: Electrophysiological evidence for differential sensitivity to dopamine agonists. Science 206: 80-82.

Sparks D. L. and Slevin J. T. (1985) Determination of tyrosine, tryptophan and their metabolic derivatives by liquid -chromatography-electrochemical detection: Application to post mortem samples from patients with
Parkinson's and Alzheimer's disease. Life Sci. 36: 449-457.

Westerink B. H. C. and Korf J. (1976) Acidic dopamine metabolites in cortical areas of the rat brain: Localization and effects of drugs. Brain Res. 113: 429-434.

Wolf M. E. and Roth R. H. (1987) Dopamine autoreceptors. In: Receptor Biochemistry and Methodology, Vol. 8 Dopamine Receptors (Creese I. and Frazer C. M., Eds). Alan R. Liss, New York.

Zahniser N. R., Peris J., Dwoskin L. P., Curella P., Yasuda R. P., O'Keefe L. and Boyson S. J. (1988) Sensitization to cocaine in the nigrostriatal dopamine system. In: Mechanisms of Cocaine Abuse and Toxicity (Clouet. D., Asghar K. and Brown R., Eds), National Institute on Drug Abuse Research Monograph \# 88, pp. 55-77. U.S. Government Printing Office, Washington DC.

Zetterström T., Sharp T., Marsden C. A. and Ungerstedt U. (1983) In vivo measurement of dopamine and its metabolites by intracerebral dialysis: changes after $d$ amphetamine. $J$. Neurochem. 41: 1769-1773. 